\title{
Characterization of Coir Pith Ash Blended Cement Pastes
}

ISSN: 2576-8840

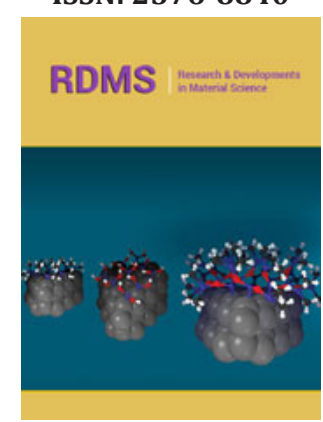

*Corresponding author: Darweesh HHM, Refractories, Ceramics and Building Materials Department, National Research Centre, Egypt

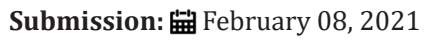

Published: 眥 March 04, 2021

Volume 15 - Issue 1

How to cite this article: Amra Bratovcic. Heterogeneous Photocatalysts Based on $\mathrm{TiO}_{2}$ for Abatement of Hazardous Air Pollutants. Res Dev Material Sci. 15(1). RDMS.000851. 2021. DOI: 10.31031/RDMS.2021.15.000851

Copyright@ Darweesh HHM. This article is distributed under the terms of the Creative Commons Attribution 4.0 International License, which permits unrestricted use and redistribution provided that the original author and source are credited.

\section{Darweesh HHM*}

Refractories, Ceramics and Building Materials Department, National Research Centre, Egypt

\begin{abstract}
More undesirable wastes or by-products are generated from the coconut and coir industry as coir pith. The raw coir pith was fired up to $500^{\circ} \mathrm{C}$ inside a suitable oven to obtain Coir Pith Ash (CPA). The effect of CPA as a supplementary cementitious material on the various specific characteristics of Portland cement pastes was investigated. Results illustrated that the blaine fineness of the whole cement blend, water of consistency and setting times increased with the increase of CPA addition. The bound water content and bulk density as well as flexural and compressive strengths improved and enhanced with the addition of CPA only up to $12 \mathrm{wt} \% \mathrm{CPA}$ (CP4), and then sharply decreased suddenly with further increase of CPA content (CP5). The free lime content of the blended cement pastes containing different ratios of CPA decreased at all hydration times and were being lower than those of the blank (CP0). The apparent porosity also gradually reduced with cement pastes containing up to $12 \mathrm{wt} \% \mathrm{CPA}$ as in the cement blend CP4, but then increase with further increase of CPA content $>12 \mathrm{wt} \% \mathrm{CPA}$ as in the cement blend CP5. The Ultrasonic Pulse Velosity (USPV) test showed that the matrix conformities of the various hardened cement pastes with CPA are well sticky and good quality.
\end{abstract}

Keywords: Cement; CPA; Consistency; Setting; Free lime; Porosity; Strength

\section{Introduction}

\section{Scope of the problem}

The utilization of by-products from the various sectors of industry and agriculture as supplementary cementitious materials is gaining popularity between researchers worldwide. These materials are not only improving the quality of products of blended cements, but also it reduces the cost and adverse effects of cement production. The fly ash [1-6], granulated slag $[7,8]$, silica fume $[6,9,10]$, metakaolin $[9,11]$, sugarcane bagasse ash [12-15], wheat straw ash [16-19], corn stalk ash [17-21], rice husk ash [22-26], saw dust ash [27-32], palm ash [33], sunflower ash [34], and many others are examples for these materials. The importance of these materials is often due to it possess pozzolanic reactivity from the active amorphous silica which undergoes secondary reactions with the released free lime, $\mathrm{Ca}(\mathrm{OH}) 2$ from the hydration of the silicate phases of the cement forming additional cementitious materials.

The annual production of coconuts in some countries like Spain, Brazil and India is nearly about 12-15 tons annually. The spongy appearance of coconuts is known as "coir pith", which is generated from coir processing unit. It could be considered as a by-product. Also, it is very interesting to note that the coir pith (CP) constitutes is about $70 \%$ of the total weight of a coconut husk [35]. Also, the rate of CP production is ranging to be 1.6 tons per 10000 coconuts [36,37]. The collected CP is usually dumped in heaps or hills. This creates many environmental problems. This is essentially attributed to its slow decay or disintegration, and moreover to its high phenolic content. In a recent study, the coir pith ash (CPA) passing through $200 \mu$ sieve has been found to possess pozzolanic characteristics and the replacement of cement by CPA improved the mechanical performance of concrete [38].

\section{Objectives of the study}

The objective of this study is to evaluate and follow the influence of coin pith ash (CPA) on the specific characteristics of Ordinary Portland cement. The obtained results were confirmed by Ultrasonic Pulse Velosity (USPV) test. 


\section{Experimental}

\section{Raw materials}

The used raw materials in the present research study are Ordinary Portland cement (OPC Type I- CEM I 42,5R) with Blaine surface area $3400 \mathrm{~cm}^{2} / \mathrm{g}$, and Waste of Coconut Pith (WCP) as a source of active nanosilica with fineness $6450 \mathrm{~cm} 2 / \mathrm{g}$ (Figure 1). The Blaine surface area was applied by the "Air Permeability Apparatus". The OPC sample was provided by Sakkara cement factory, Giza, Egypt, and its commercial name is known as "Asmant
El-Momtaz", while WCP sample was provided from a local plant, Giza, Egypt. The WCP sample was first processed and washed with running water, and also with distilled water, and then let to dry under direct sun and open air for few days. The dried WCP was subjected to firing at $500{ }^{\circ} \mathrm{C}$ inside a suitable muffle furnace for five hours soaking time, and then was left to cool gradually to room temperature to produce what is known as Coconut Pith Ash (CPA) as shown in Figure 1. Then, the resulting CPA was screened to pass through $200 \mu \mathrm{m}$ standard sieve [38].
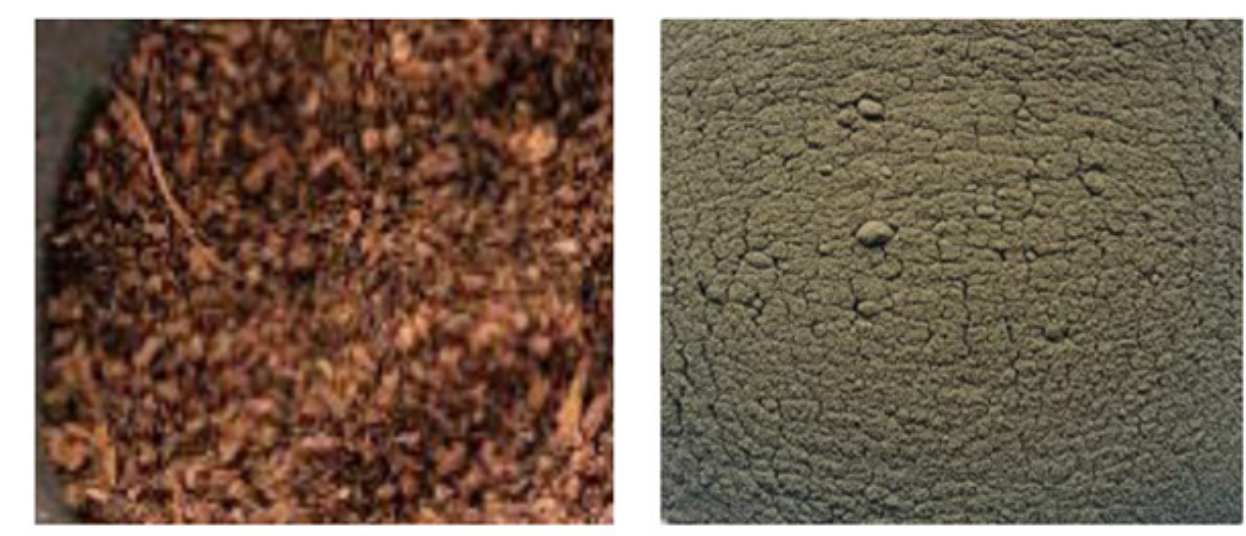

Figure 1: Coin pith (CP) and Coin pith ash (CPA).

Table 1: Composition of the used raw materials, mass \%.

\begin{tabular}{|c|c|c|c|c|c|c|c|c|c|c|c|}
\hline $\begin{array}{c}\text { Oxid } \\
\text { Material }\end{array}$ & $\mathrm{SiO}_{2}$ & $\mathrm{Al}_{2} \mathrm{O}_{3}$ & $\mathrm{Fe}_{2} \mathrm{O}_{3}$ & $\mathrm{CaO}$ & MgO & Mno & $\mathrm{SO}_{3}$ & $\mathrm{Na}_{2} \mathrm{O}$ & $\mathbf{P}_{2} \mathbf{O}_{5}$ & $\mathrm{~K}_{2} \mathbf{O}$ & LOI \\
\hline OPC & 19.36 & 4.68 & 3.18 & 61.67 & 1.03 & 0.21 & 2.27 & 0.35 & 0.09 & 0.30 & 1.64 \\
\hline CPA & 48.23 & 2.31 & 2.63 & 15.12 & 2.96 & 0.03 & --- & 3.75 & --- & 0.61 & 2.13 \\
\hline
\end{tabular}

Table 2: Mineralogical composition of the used OPC sample, mass \%.

\begin{tabular}{|c|c|c|c|c|}
\hline Phase & $\mathrm{C}_{3} \mathbf{S}$ & $\boldsymbol{\beta}-\mathrm{C}_{2} \mathbf{S}$ & $\mathrm{C}_{3} \mathbf{A}$ & $\mathrm{C}_{4} \mathrm{AF}$ \\
\hline Material & 43.01 & 30.00 & 5.65 & 9.58 \\
\hline OPC & & & \\
\hline
\end{tabular}

Table 3: The batch composition of cement mixtures, mass \%.

\begin{tabular}{|c|c|c|c|c|c|c|c|c|c|c|}
\hline $\begin{array}{c}\text { Batch } \\
\text { Material }\end{array}$ & CP0 & CP1 & CP2 & CP3 & CP4 & CP5 & CP6 & $\begin{array}{l}\text { Densit, } \\
\mathrm{g} / \mathrm{cm}^{3}\end{array}$ & $\begin{array}{l}\text { Blaine Finene } \\
\mathrm{cm}^{2} / \mathrm{g}\end{array}$ & $\begin{array}{l}\text { Specific } \\
\text { Gravity }\end{array}$ \\
\hline OPC & 100 & 97 & 94 & 91 & 88 & 85 & 82 & 2.2215 & 3400 & 3.14 \\
\hline CPA & ---- & 3 & 6 & 9 & 12 & 15 & & 2.6546 & 6810 & 3.31 \\
\hline $\begin{array}{l}\text { Fineness, } \\
\mathrm{cm}^{2} / \mathrm{g}\end{array}$ & 3400 & 3464 & 3561 & 3707 & 3873 & 4081 & 4220 & & & \\
\hline
\end{tabular}

The chemical composition of the OPC and CPA measured by X-ray Florescence Technique (XRF) is shown in Table 1. The mineralogical phase composition of the used OPC as calculated from Bogue equations $[39,40]$ is given in Table 2, while the mix composition is illustrated in Table 3. The CPA nanoparticles are amorphous and crystalline, and it is mainly composed of a large percentage of nano-SiO2 and a lower percentage of nano- $\mathrm{Al}_{2} \mathrm{O}_{3}$.

\section{Preparation and Methods}

There are eight cement batches from OPC and CPA as 100:0, 97:3, 94:6, 91:9, 88:12 and 85:15. These cement batches were given the symbols: CP0, CP1, CP2, CP3, CP4 and CP5, respectively. The blending process was mechanically made in a porcelain ball mill containing three balls for one hour to assure the complete 
homogeneity of all cement batches. Before casting of cement cubes, all moulds were oiled with a thin film of motor engine oil, to facilitate the release of the cubes from the moulds during the demoulding. A mechanical mixing was used for all cement mixtures using a suitable laboratory mechanical mixer in order to obtain homogenous mixtures. Firstly, the standard water of consistency [41-43] as well as setting time $[44,45]$ of the various cement pastes were directly determined using Vicat Apparatus (Figure 2).

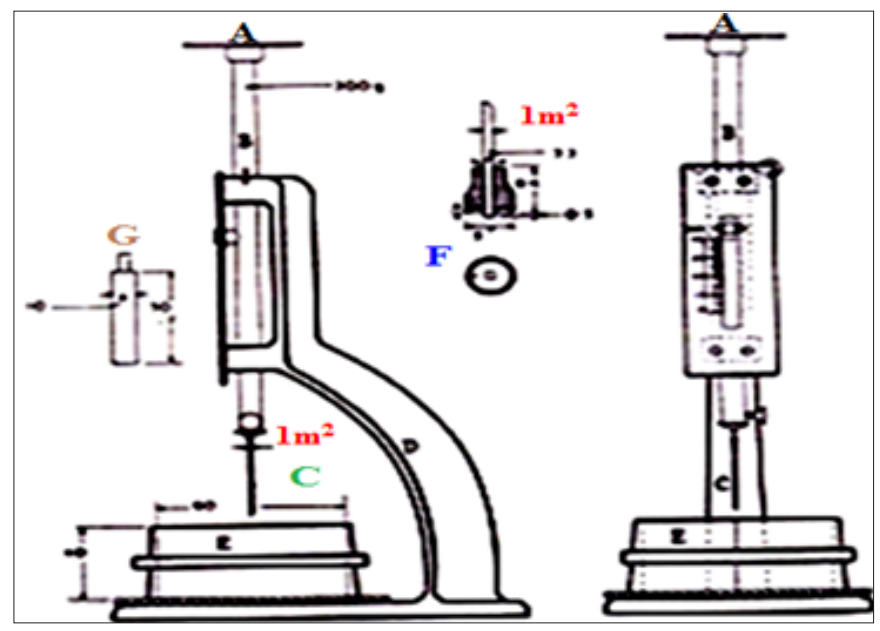

Figure 2: Vicat apparatus for water consistency and setting times.

\section{Methods}

The water of consistency could be determined from the following relation:

$$
\text { WC, \%=A/C x } 100 \text { (1) }
$$

Where, A is the amount of water taken to produce a suitable paste, $C$ is the amount of cement mix $(300 \mathrm{~g})$. The initial setting time was measured by calculating the time taken from the moment at which the needle could penetrate to the paste up to $5 \mathrm{ml}$ from the bottom, while the final setting time was calculated by measuring the time taken from the moment at which the water added to the cement till the final set when the impression of the needle disappeared on the surface of the pastes. During the dry mixing process, the right $\mathrm{w} / \mathrm{c}$-ratio was poured into the cement portion inside the mixer and then run the mixer for about 10 minutes at an average speed of 10rpm in order to have a perfect homogenous mixture. During casting of the cement cube moulds, each already prepared oil mould was filled with the premixed cement composite and rammed 10 minutes to eliminate all air bubbles tapped within the mixture. The moulds were filled to the top surface and smoothed with a flat stainless steel trowel or spatula to obtain a flat smooth surface. The cement pastes were then cast using the predetermined water of consistency, moulded into rod-shaped samples of $1 \mathrm{x} 1 \mathrm{x}$ $7 \mathrm{~cm} 3$ and cubic-shaped samples of $2.5 \times 2.5 \times 2.5 \mathrm{~cm} 3$ stainless steel moulds using about $500 \mathrm{~g}$ cement mix for each sample, vibrated manually for three minutes and then on a mechanical vibrator for another three minutes. The surface of the moulds was smoothed using a suitable trowel or spatula. After casting all cement cubes, they were covered with a black wet sheet for the first 24 hours to prevent moisture loss. Thereafter, the moulds were kept in a humidity chamber for 24 hours under $100 \%$ relative humidity and room temperature $23 \pm 1{ }^{\circ} \mathrm{C}$. In the following day, it demoulded and soon cured under water till the time of testing at 1, 3, 7, 28 and 90 days.

At each hydrating interval, the Bulk Density (BD) and Apparent Porosity (AP) of the hardened cement pastes $[19,30,31,37,46]$ were calculated from the following equations:
B. D, $\left(\mathrm{g} / \mathrm{cm}^{3}\right)=\mathrm{W} 1 /(\mathrm{W} 1-\mathrm{W} 2) \times 1(2)$
A. P, $\%=(W 1-W 3) /(W 1-W 2) \times 100(3)$

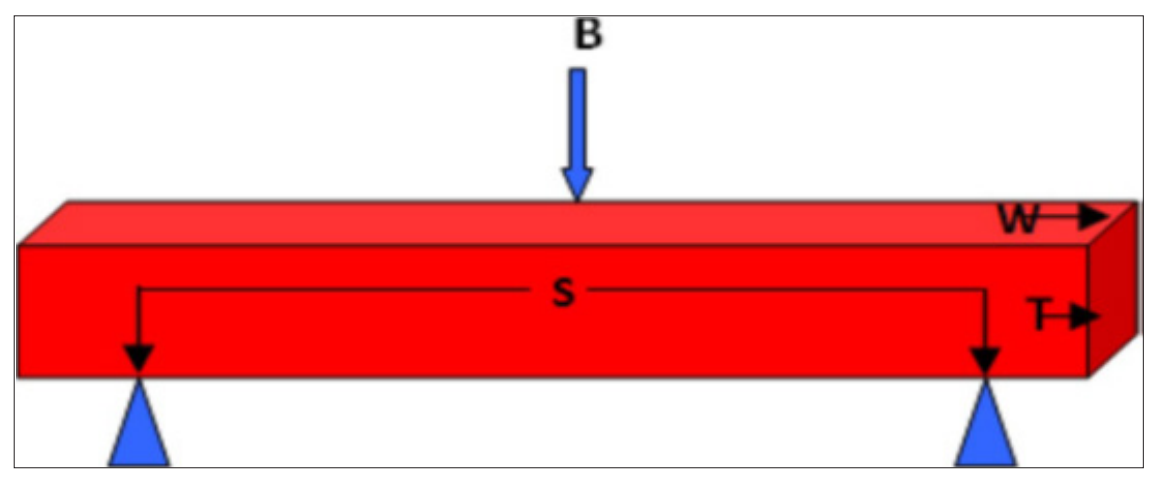

Figure 3: Schematic diagram of the bending strength (B: beam or load, S: spam, T: thickness, W: width). 
Where, W1, W2 and W3 are the saturated, suspended and dry weights, respectively. The rod-shaped samples were subjected to flexural strength using a simple beam with three points loading system (Figure 3), which was determined from the following equation:

$$
\text { F. S, } \mathrm{kg} / \mathrm{cm}=3 \text { (PL)/ } 2 \text { (b) (d) / 10.2 MPa (4) }
$$

Where, where, B: the load of rupture, kg, S: span or the distance between the two lower beams $(5 \mathrm{~cm}), \mathrm{W}$ : width of sample, $\mathrm{cm}$ and T: thickness of sample, $\mathrm{cm}$.

The Compressive Strength (CS) of the various hardened cement pastes $[47,48]$ was measured using a suitable Piston as follows:

$$
\mathrm{CS}=\mathrm{L}(\mathrm{KN}) / \mathrm{Sa}\left(\mathrm{cm}^{2}\right) \mathrm{KN} / \mathrm{m}^{2} \times 102\left(\mathrm{Kg} / \mathrm{cm}^{2}\right) / 10.2(\mathrm{MPa})(5)
$$

Where $\mathrm{L}$ is the load taken, Sa is the surface area. Thereafter about 10 grams of the broken specimens from the determination of compressive strength were first well ground, dried at $105^{\circ} \mathrm{C}$ for $30 \mathrm{~min}$. and then were placed in a solution mixture of 1:1 methanol: acetone to stop the hydration $[6,10,11,14,25,32-34,39,40]$. The kinetics of hydration in terms of chemically bound water and free lime contents were also measured at each hydration age on the basis of ignition loss at $1000{ }^{\circ} \mathrm{C}$ for 30 minutes soaking. About one gram of the sample was placed inside a crucible and first dried at $105{ }^{\circ} \mathrm{C}$ for 24 hours, and then the crucibles were placed into a furnace $[6,19,34,42,46]$. The chemically bound water content (CBn) at each hydration age was determined as follows:

$$
\text { CBn, \% = W1-W2/W2 x } 100(6)
$$

Where, BWn, W1 and W2 are combined water content, weight of sample before and after ignition, respectively.

The free lime content (FLn) of the hydrated samples predried at $105{ }^{\circ} \mathrm{C}$ for $24 \mathrm{~h}$ was also determined. About $0.5 \mathrm{~g}$ sample $+40 \mathrm{ml}$ ethylene glycol $\rightarrow$ heating to about 20 minutes without boiling. About 1-2 drops of $\mathrm{pH}$ indicator were added to the filtrate and then titrated against freshly prepared $0.1 \mathrm{~N} \mathrm{HCl}$ until the pink colour disappeared. The $0.1 \mathrm{~N} \mathrm{HCl}$ was prepared using the following equation: Where, Wn, W1 and W2 are combined water content, weight of sample before and after ignition, respectively. The free lime content of the hydrated samples pre-dried at $105^{\circ} \mathrm{C}$ for $24 \mathrm{~h}$ was also determined. About $0.5 \mathrm{~g}$ sample $+40 \mathrm{ml}$ ethylene glycol $\rightarrow$ heating to about 20 minutes without boiling. About 1-2 drops of $\mathrm{pH}$ indicator were added to the filtrate and then titrated against freshly prepared $0.1 \mathrm{~N} \mathrm{HCl}$ until the pink colour disappeared. The $0.1 \mathrm{~N} \mathrm{HCl}$ was prepared using the following equation:

$$
\mathrm{V} 1=\mathrm{N} \times \mathrm{V} 2 \times \mathrm{W}(7) \times 100 / \mathrm{D} \times \mathrm{P} \times 1000(7)
$$

Where, V1 is the volume of $\mathrm{HCl}$ concentration, V2 is the volume required, $\mathrm{N}$ is the normality required, $\mathrm{W}$ is the equivalent weight, $\mathrm{D}$ is the density of $\mathrm{HCl}$ concentration and $\mathrm{P}$ is the purity (\%). The heating and titration were repeated several times until the pink colour did not appear on heating. The free lime content $[10,14,19,25,39,40,45]$ was calculated from the following relation:

FLn, $\%=(\mathrm{V} \times 0.0033 / 1) \times 100(8)$

Where, FLn and V are the free lime content and the volume of $0.1 \mathrm{~N} \mathrm{HCl}$ taken on titration, respectively.

The obtained results were confirmed with Ultrasonic Pulse Velocity (USPV) test [49] which is one of the prominent NonDestructive Testing (NDT) methods. It is mainly carried out to assess the uniformity and relative quality of existing structures and specimens [50]. The test was carried out on 1, 3, 7, 28 and 90 days.

\section{Results and Discussion}

\section{Water of consistency}

The water of consistency of the control OPC cement pastes (CP0) and the various cement pastes containing different ratios of CPA (CP1-CP6) is graphically plotted in Figure 4. As it is clear, the water of consistency of the control cement pastes (CP0) was found to be $29.55 \%$. This value increases gradually with the increase of CPA content. This mainly is attributed to that the CPA wanted more water to produce suitable cement pastes with satisfied workability, i.e., it is very voracious to water $[4,6,8,14,39,40]$. In normal cases, the quantities of water needed to form suitable pastes are being higher than those of the obtained values.

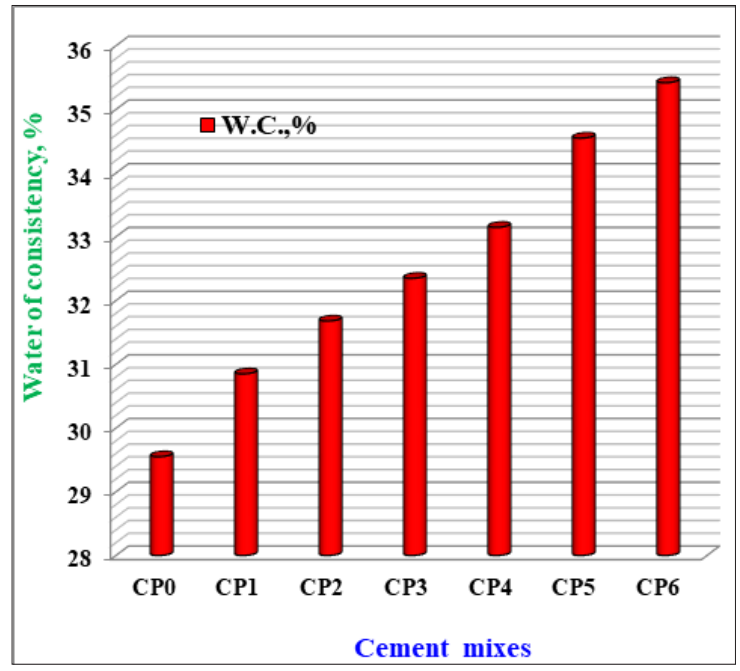

Figure 4: Water of consistency of the various cement pastes (CP0-CP6). 


\section{Setting times}

The setting times (Initial and final) of the control OPC cement pastes ( $\mathrm{CP} 0)$ and the various cement pastes containing different ratios of CPA (CP1-CP6) are also represented in Figure 5. The setting times were also increased with the increase of CPA content. This is principally contributed to the increase of mixing water to produce suitable cement pastes with good workability [4,8,16,21,34,37]. Moreover, the very low atmospheric temperature during carrying out the test is another factor to increase the setting times.

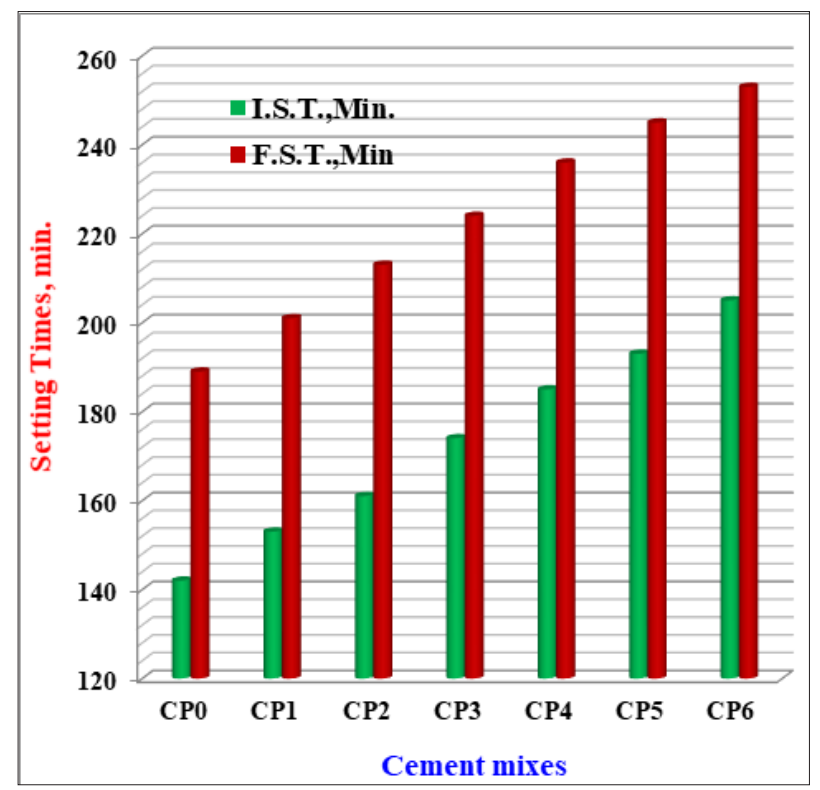

Figure 5: Setting times (Initial and final) of the various cement pastes (CP0-CP6).

\section{Chemically bound water content}

The results of chemically bound water contents of the various cement/CPA blended cement pastes are represented as a function of hydration ages up in 90 days in Figure 6. Generally, the bound water contents of all cement pastes increased with the increase of hydration ages up to 90 days. Furthermore, the bound water contents also improved and enhanced with CPA content only up to 12 wt. \% (CP4), and then decreased with further increase of CPA content (CP5). The increase of the bound water is essentially due to two main factors. The first is the normal hydration of the major cement phases, while the second is due to the pozzolanic activity of the CPA, where the constituents of CPA could be reacted with those resulting from the hydrated cement phases like $\mathrm{Ca}(\mathrm{OH}) 2$ to produce CSH and/or CAH $[30,33,34,37]$. On the other side, the decrease of bound water contents is attributed to the lack or deficiency of the main hydrating materials of the cement due to its substituted by CPA $[16,18,20,37,39,40]$.

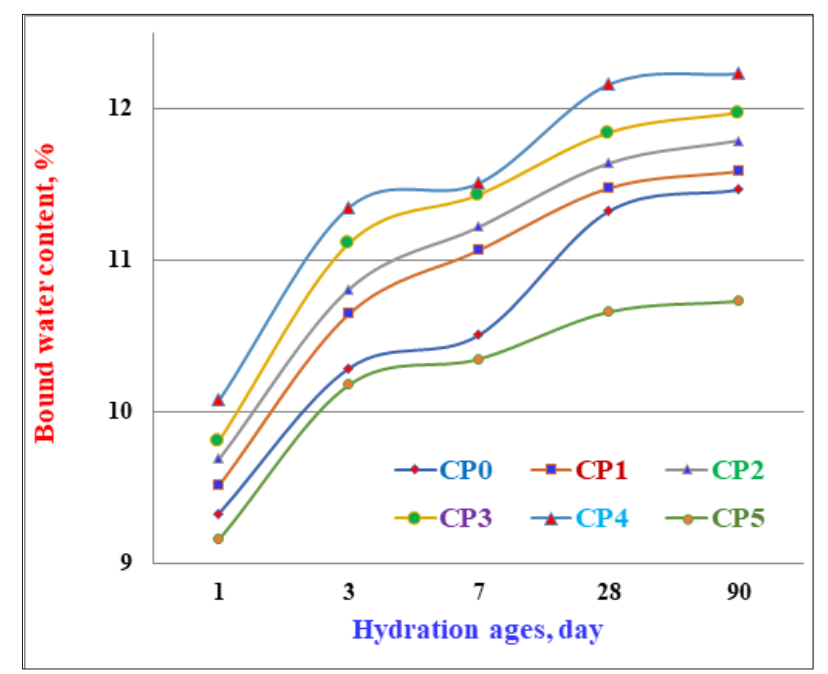

Figure 6: Bound water content of the various cement pastes (CP0-CP6) hydrated up to 90 days. 


\section{Free lime content}

The results of free lime contents of the various cement/CPA blended cement pastes are plotted as a function of hydration ages in Figure 7. It is obvious that the free lime content of the blank cement (CP0) was increased with the increase of hydration age, i.e., as the hydration times proceeded up to 90 days, the free lime contents increased too. This is mainly attributed to the hydration of silicate phases of the cement, C3S during the early ages of hydration (1-7 days), while $\beta$-C2S often hydrated at the later hydration time
(28-90 days) $[39,40]$. On contrast, the free lime contents of the other cement pastes containing different ratios of CPA decreased with the hydration periods up to 90 days, only up to $12 \mathrm{wt} \% \mathrm{CPA}$ (CP4). This is essentially due to the pozzolanic reactions occurred between the constituents of CPA and the resulting free lime, $\mathrm{Ca}(\mathrm{OH}) 2$ from the hydration silicate phases of the cement to form CSH $[16,19,25,30,34,37]$. Furthermore, the deficiency of the cement portion due to the addition of CPA at the expense of the cement led to the decrease of the rate of hydration, which in turn led to the decrease of the released free lime [30-34,37,38].

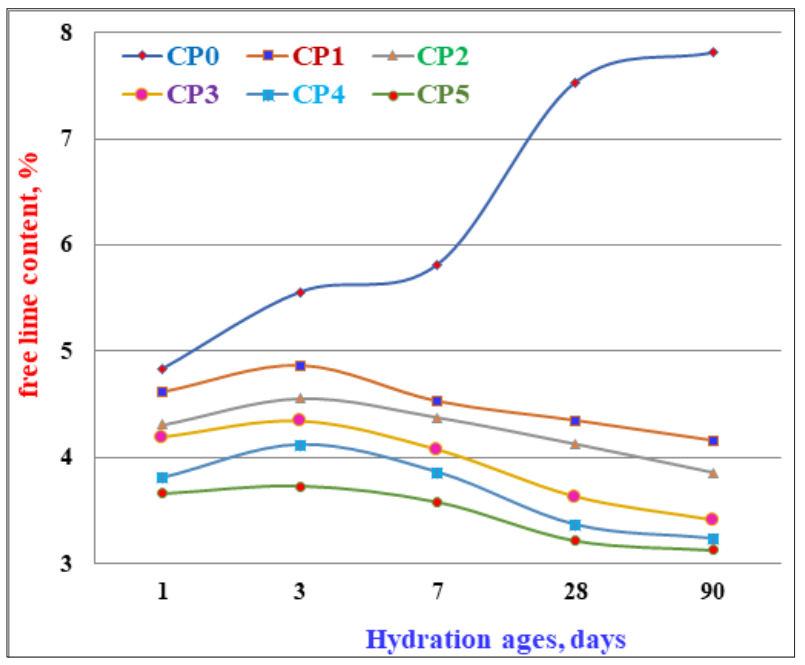

Figure 7: Free lime content of the various cement pastes (CP0-CP6) hydrated up to 90 days.

\section{Bulk density and apparent porosity}

The data of bulk density and apparent porosity of the various cement/CPA blended cement pastes are drawn as a function of hydration ages up to 90 days in Figures 8 \& 9, respectively. The values of bulk density of the various blended cement slightly increased with time of hydration till reach to 90 days, while those of apparent porosity decreased $[39,40]$. With the increase of CPA content, the bulk density improved and enhanced at all hydration times when compared with the blank (PC0), whereas the apparent porosity decreased. This was continued till reach to $12 \mathrm{wt}$. \% CPA (CP4), but then decreased with further increase of CPA content (CP5), and the apparent porosity increased [13-16,20,21,26,37]. As a result, the optimum content of CPA is $12 \mathrm{wt}$. \% (CP4). It is good remember that the higher quantities of CPA (>12 wt. \%) must be neglected and avoided.

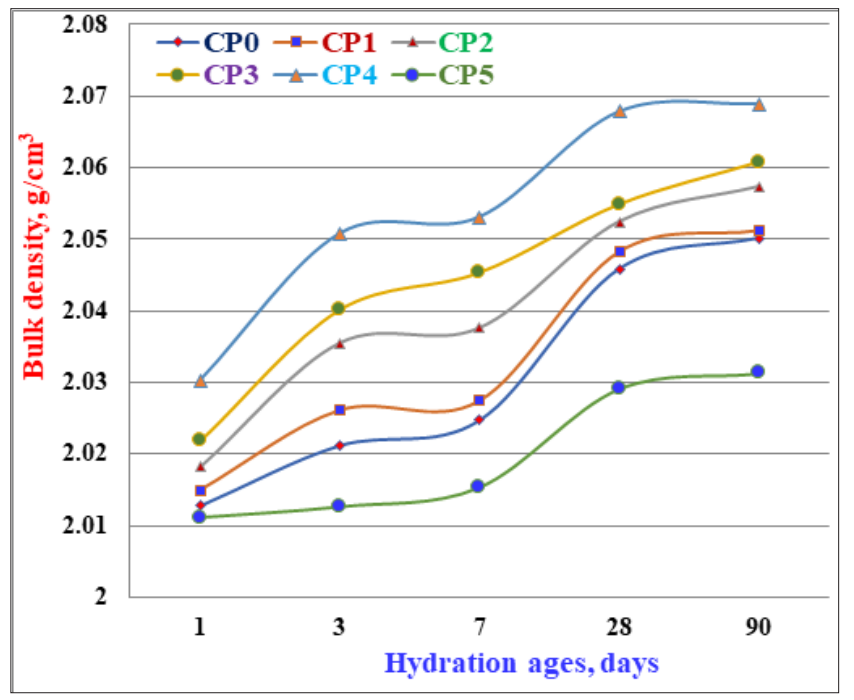

Figure 8: Bulk density of the various cement pastes (CP0-CP6) hydrated up to 90 days. 


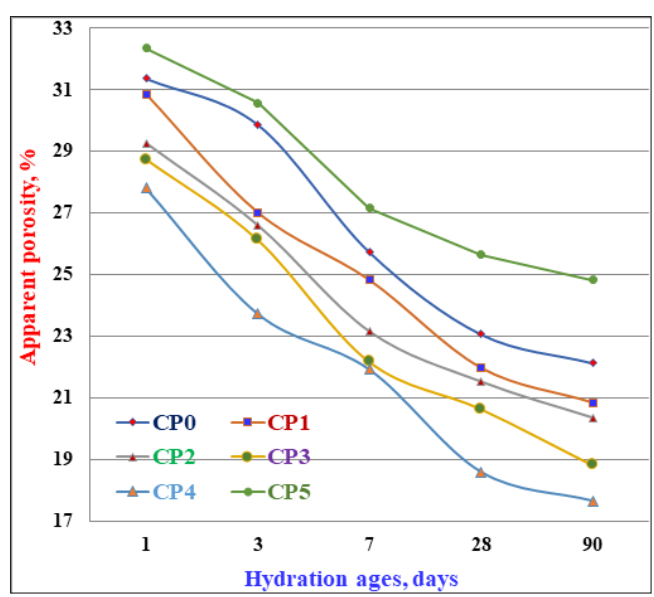

Figure 9: Apparent porosity of the various cement pastes (CP0-CP6) hydrated up to 90 days.

\section{Flexural strength}

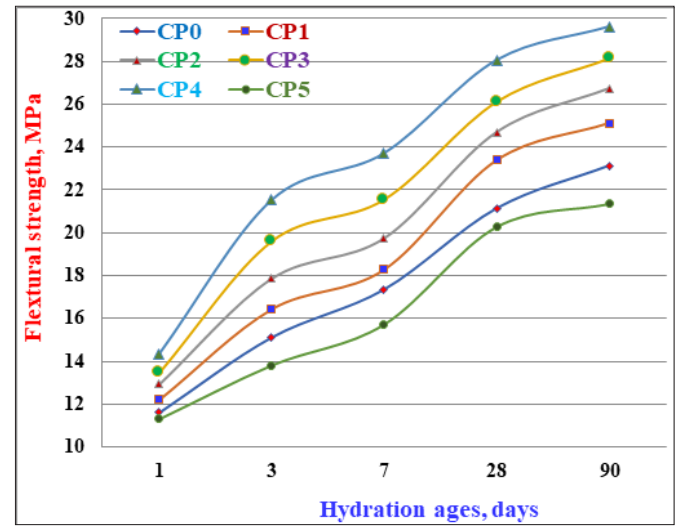

Figure 10: Flexural strength of the various cement pastes (СP0-СР6) hydrated up to 90 days.

The flexural strength of the various cement/CPA blended cement pastes is graphically plotted versus hydration ages up to 90 days in Figure 10. The flexural strength is generally enhanced with hydration ages for all cement blends $[13,16,19,21,30,34,39,40]$. Moreover, the flexural strength improved and increased with the increase of CPA content up till 12wt. \% (CP4), but then decreased with any further increase of CPA content (CP5). Consequently, the optimum cement blend is that containing $12 \mathrm{wt}$. \% CPA, and the high amounts are undesirable.

\section{Compressive strength}

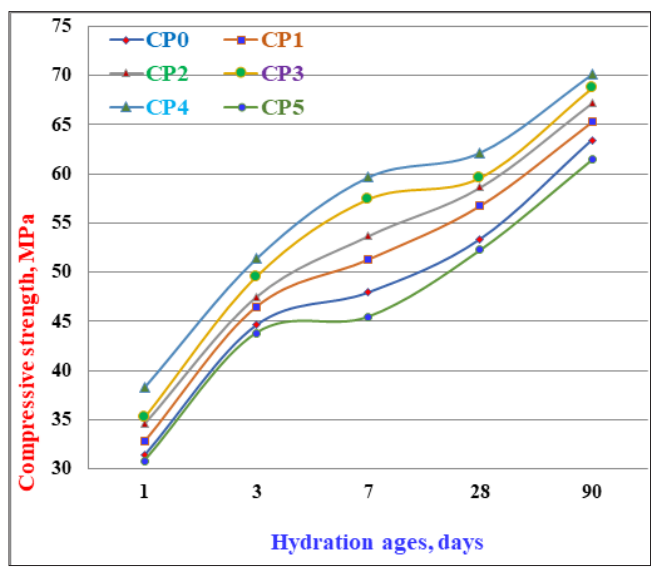

Figure 11: Compressive strength of the various cement pastes (CP0-CP6) hydrated up to 90 days. 
The compressive strength of the various cement/CPA blended cement pastes is graphically represented as a function of hydration ages up to 90 days in Figure 11. The compressive strength was observed to increase with curing times up to 90 days, i.e., as the hydration ages proceeded, the compressive strength gradually increased, This is mainly due to the normal hydration process of cement phases, particularly those of calcium silicate (C3S and C2S) $[39,40]$. On the other side, as the CPA content increased in the cement pastes, the compressive strength increased only up to CP4 containing $12 \mathrm{wt} \% \mathrm{CPA}$, but then decreased with the further increase of CPA content. The increase of compressive strength is essentially attributed to the pozzolanic reactivity of CPA with the evolved $\mathrm{Ca}(\mathrm{OH}) 2$ resulting from the hydration silicate phases of the cement $[32,34,41-47]$, while the decrease of compressive strength is particularly contributed to the deficiency of the main hydration material of the cement, which in turn decreased the rate of hydration [18,21,30,48-51]. In addition, the rate of pozzolanic reactions also decreased. So, the higher content of CPA content is undesired and must be avoided. This is due to the fact that the higher quantity of CPA acted as an obstacle that hindered the process of hydration. As a result, it could be concluded that the optimum content of CPA is only 12 wt \% (CP4).

\section{Ultrasonic pulse velocity test}

There are several Non-Destructive Testing Methods (NDTM) that are able to test the hardened cement samples without destructing it. Ultra-sonic Pulse Velocity Method (USPV) is one of these prominent methods NDTM and it is carried out mainly to assess the uniformity and relative quality of existing structures and specimens. On this basis, the Ultrasonic Pulse Velocity (USPV) of the various hardened cement/CPA blended cement pastes is graphically drawn versus the hydration ages up to 90 days in Figure 12. As it is obvious, the USPV of the blank (CP0) increased only up to 7 days, and then tended to become constant. This means that the various ingredients or constituents of the blank did not affect by the ultrasonic pulse velocity $[38,52]$. The same trend was displayed by all other blended cement pastes. Accordingly, the USPV test proved that the conformities of the matrix of the various cement pastes are well sticky and with good quality, i.e., good uniformity and conformity as well as no cracks $[53,54]$. The gradual increase of pozzolanic reactions of CPA, due to its high level of its grain size particles, with the evolved $\mathrm{Ca}(\mathrm{OH}) 2$ resulting from the hydration of calcium silicate phases of the cement was the main reason responsible for the quality uniformity of the cement matrix [52].

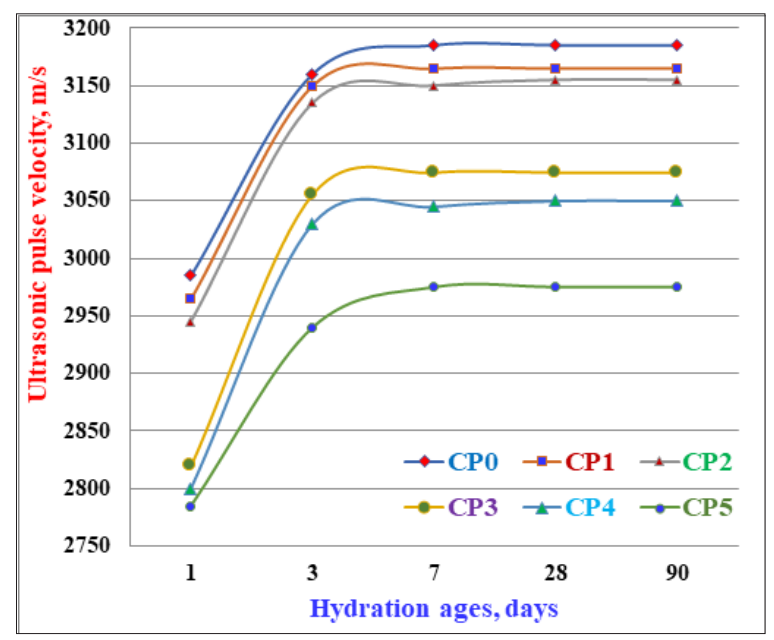

Figure 12: The ultrasonic pulse velocity of the hardened cement pastes containing various ratios of CPA versus hydration ages

\section{Conclusion}

Concerning the findings of the laboratory test results, the following overall conclusions could be obtained:

1. As the content of active nano-silica particles from CPA increased in the cement blend, the Blaine fineness of the whole cement batches increased too.

2. The water of consistency of the blank (CP0) was 29.55 $\%$, and its initial and final setting times were 142 and 189 minutes. These values tended to increase with the increase of CPA content. This is mainly due to the fact that the CPA is so gluttonous that it needs much water to produce suitable pastes.

3. The bound water content of the different blended cement pastes (CP0-CP5) increased continuously with hydrating ages up to 90 days. But the bound water content of the blended cement pastes containing CPA up to $12 \mathrm{wt}$ \% (CP4) increased more and are beining slightly higher than those of the blank (CP0), and then decreased with further increase of CPA content (CP5).

4. The free lime content of the blank ( $\mathrm{CP} 0$ ) increased as the hydrating time progressed up to 90 days, while those of other blended cement pastes containing different ratios of CPA (CP1CP5) decreased as the hydration time proceeded up to 90 days.

5. As the cement powder becomes in contact with water, the hydration process started soon and the apparent porosity was soon diminished and reduced due to the deposition of the formed hydration products in the pore structure of the hardened samples. Therefore, the apparent porosioty decreased while 
the bulk density increased. This is still taking place only up to replace $12 \mathrm{wt} \% \mathrm{CPA}$ content (C4).

6. The mechanical properties in terms of flexural and compressive strengths were also investigated. Generally, the flexural and compressive strengths were increased as the hydration times progressed up to 90 days for all blended cement pastes. The compressive strength displayed the same trend as flextural strength.

7. The addition of $12 \%$ CSA (CP4) to Portland cement could be successfully applied without any adverse effects on the physical, chemical and mechanical properties of Portland cement. Therefore, it was selected to be the optimum batch.

8. The USPV test proved that the conformities of the matrix of the various cement pastes are well sticky and of good quality, i.e., good uniformity or good conformity, and no cracks

\section{Acknowledgement}

The author wishes to express his deep thanks to National Research Centre for helping to obtain materials, processing, preparing, molding and measuring all of the obtained data of the study, and moreover for financial assistance.

\section{References}

1. Bhanumathidas N, Mehta PK (2001) Concrete mixtures made with ternary blended cements containing fly ash and rice-husk ash. Special Publication 199: 379-392.

2. Siddique R (2011) Properties of self-compacting concrete containing class F fly ash. Mater Des 32: 1501-1507.

3. Fan WJ, Wang XY, Park KP (2015) Evaluation of the chemical and mechanical properties of hardening high calcium fly ash blended concrete. Materials 8: 5933-5952.

4. Darweesh HHM, Abo-El-Suoud MR (2015) Quaternary cement composites containing some industrial by-products to avoid the environmental pollution. EC Chemistry 2(1): 78-91.

5. Rashad MA (2015) A brief on high-volume class F fly ash as cement replacement - a guide for civil engineer. Int J Sustain Built Environ 4: 278-306.

6. Darweesh HHM (2017) Geopolymer cements from slag, fly ash and silica fume activated with sodium hydroxide and water glass. Interceram International 6(1): 226-231.

7. Oner A, Akyuz S (2007) An experimental study on optimum usage of GGBS for the compressive strength of concrete. Cement and Concrete Composites 29(6): 505-514.

8. Darweesh HHM (2012) Setting, hardening and strength properties of cement pastes with zeolite alone or in combination with slag. Interceram Intern (Intern Cer Review), Germany, 1: 52-57.

9. Ding JT, Li Z (2002) Effects of metakaolin and silica fume on properties of concrete. Materials Journal 99(4): 393-398.

10. Darweesh HHM (2017) Mortar composites based on industrial wastes. International Journal of Materials Lifetime 3(1): 1-8.

11. Darweesh HHM (2020) Metakaolin blended cement pastes. International Journal of Innovative Studies in Sciences and Engineering Technology 6(1): 5-18.
12. Cordeiro GC, Toledo Filho RD, Tavares LM, Fairbairn EMR (2008) Pozzolanic activity and filler effect of sugar cane bagasse ash in Portland cement and lime mortars. Cement and Concrete Composites 30(5): 410418.

13. Abdulkadir TS, Oyejobi DO, Lawal AA (2014) Evaluation of sugarcane bagasse ash as a replacement for cement in concrete. Acta Tehnica Corviniensis - Bulletin of Engineering, (University of Ilorin, Nigeria), pp: 71-76.

14. Darweesh HHM, Abo El-Suoud MR (2019) Influence of sugarcane bagasse ash substitution on Portland cement characteristics. Indian Journal of Engineering 16: 252-266.

15. Garrett TD, Cardenas HE, Lynam JG (2020) Sugarcane bagasse and rice husk ash pozzolans: Cement strength and corrosion effects when using saltwater. Current Research in Green and Sustainable Chemistry 1-2: 7-13.

16. Biricik H Aköz F, Lhan Berktay I, Tulgar AN (1999) Study of pozzolanic properties of wheat straw ash. Cement and Concrete Research 29(5): 637-643.

17. Aksogan O, Binici H, Ortlek E (2016) Durability of concrete made by partial replacement of fine aggregate by colemanite and barite and cement by ashes of corn stalk, wheat straw and sunflower stalk ashes. Construction and Building Materials 106: 253-263.

18. Binici H, Ortlek E (2015) Engineering properties of concrete made with cholemanite, barite, corn stalk, wheat straw and sunflower stalk ash. European Journal of Engineering and Technology 3(4): 1-12.

19. Darweesh HHM, Abo El-Suoud MR (2020) Specific characteristics and microstructure of Portland cement pastes containing Wheat Straw Ash (WSA). Indian Journal of Engineering 17(48): 569-583.

20. Raheem AA, Aedokun SI, Adeyinka EA, Adewole BV (2017) Application of cornstalk ash as partial replacement for cement in the production of interlocking paving stones. International Journal of Engineering Research in Africa 30: 85-93.

21. Darweesh HHM (2020) Physico-mechanical properties and microstructure of Portland cement pastes replaced by corn stalk ash (CSA). Intern Journal of Chemical Research and Development 2(1): 2433.

22. Khan R' Jabbar A, Ahmad I, Khan W, Khan AN, Mirza J (2012) Reduction in environmental problems using rice-husk ash in concrete. Construction and Building Materials 30: 360-365.

23. Madandoust R, Ranjbar MM, Moghadam HA, Mousavi SY (2011) Mechanical properties and durability assessment of rice husk ash concrete. Biosystems Engineering 110(2): 144-152.

24. Karim MR, Zain MFM, Jamil M (2012) Strength of mortar and concrete as influenced by rice husk ash: A review. World Applied Sciences Journal 19(10): 1501-1513.

25. Darweesh HHM, Abo El-Suoud MR (2014) Setting, hardening and mechanical properties of some cement / agrowaste composites - Part I. American Journal of Mining and Metallurgy 2(2): 32-40.

26.Zareei SA, Ameri F, Dorostkar F, Ahmadi M (2017) Rice husk ash as a partial replacement of cement in high strength concrete containing micro silica: Evaluating durability and mechanical properties. Case Studies in Construction Materials 7: 73-81.

27. Elinwa AU, Ejeh SP, Mamuda AM (2008) Assessing of the fresh concrete properties of self-compacting concrete containing sawdust ash. Construction and Building Materials 22(6): 1178-1182.

28. Mageswari M, Vidivelli B (2009) The use of sawdust ash as fine aggregate replacement in concrete. Journal of Environmental Research and Development 3(3): 720-726. 
29. Raheem AA, Olasunkanmi BS, Folorunso CS (2012) Saw dust ash as partial replacement for cement in concrete. Intern Journ of Organization Technology and Management in Construction 4(2): 474-479.

30. Onwuka DO, Anyaogu L, Chijioke C, Okoye PC (2013) Prediction and optimization of compressive strength of sawdust ash-cement concrete using scheffe's simpex design. Intern Journ of Sci and Res Pub 3(5): 1-9.

31. Elinwa AU, Abdulkadir S (2011) Characterizing sawdust ash for use as an inhibitor for reinforcement corrosion. New Clues in Science, pp: 1-10.

32. Darweesh HHM, Abo El-Suoud MR (2018) Saw dust ash substitution for cement pastes-Part I. American J of Construction and Building Materials 2(1): $1-9$.

33. Darweesh HHM, Abo El-Suoud MR (2020) Palm ash as a pozzolanic material for portland cement pastes. To Chemistry Journal 4: 72-85.

34. Darweesh HHM (2020) Influence of Sun Flower Stalk Ash (SFSA) on the behavior of Portland cement pastes. Results in Engineering 8: 100171.

35. FAO, FAO statistical yearbook (2014) Food and agriculture organization of the United Nations.

36. Fontenele RES (2005) Coconut culture in Brazil: current market characterization and future prospects, In XLIII Congress of Sober Ribeirão Preto, SP, Brasil.

37. Ravindranath DA, Radhakrishnan S (2016) Coir pith-wealth from waste-A reference. Published on the Occasion of the India International Coir Fair.

38. Venugopal B, Sambamurthy V (2018) Development and performance evaluation of coir pith ash as supplementary cementitious material in concrete. Journal of Engineering and Technological Sciences 50(6): 856869.

39. Neville AM (2011) Properties of concrete. ( $5^{\text {th }}$ edn), Longman, Essex, UK.

40. Hewlett PC, Liska M (2017) Lea's chemistry of cement and concrete, $\left(5^{\text {th }}\right.$ edn), Edward Arnold Ltd, London, England.

41. Topçu I B, Ateşin Ö (2016) Effect of high dosage lignosulphonate and naphthalene sulphonate based plasticizer usage on micro concrete properties. Construction and Building Materials 120: 189-197.

42. Darweesh, HHM (2020) Characteristics of portland cement pastes blended with silica nanoparticles. To Chemistry 5: 1-14.
43. ASTM-C187-86 (1993) Standard test method for normal consistency of hydraulic cement. pp: 148-150.

44.ASTM-C191-92 (1993) Standard test method for setting time of hydraulic cement. pp: 866-868

45.ASTM-Standards C191-13 (2013) Standard test method for time of setting of hydraulic cement by vicat needle. ASTM International West Conshohocken, USA.

46. Darweesh HHM (2020) Cement pastes containing polypropylene fibers - Part I: Physical, chemical and mechanical properties. To Chemistry Journal 5: 69-81.

47. ASTM-Standards-C170-90 (1993) Standard test method for compressive strength of dimension stone. pp: 828-830.

48. ASTM-C109M (2013) Standard test method for compressive strength of hydraulic cement mortars (Using 2-in. Or [50mm] Cube Specimens), Annual Book of ASTM Standards. ASTM International, West Conshohocken, PA, USA.

49. ASTM C597-09 (2009) Standard test method for pulse velocity through concrete.

50. (1992) Bureau of Indian standards, non-destructive testing of concrete -methods of test, Part 1: Ultrasonic pulse velocity, IS 13311 (Part 1), New Delhi, India, pp: 1999-2028.

51. Alex J, Dhanalakshmi J, Ambedkar B (2016) Experimental investigation on rice husk ash as cement replacement on concrete production. Construction and Building Materials 127: 353-362.

52. Balagopal V, Viswanathan TS (2020) Evaluation of mechanical and durability performance of coir pith ash blended cement concrete. Civil Engineering and Architecture 8(5): 1028-1038.

53. Balagopal V, Sambamurthy V (2020) Performance evaluation of coir pith ash blended cement concrete exposed to elevated temperature. Jurnal Teknologi 82(2).

54. Balagopal V, Viswanathan TS (2020) Effect of elevated temperature on performance of concrete containing supplementary cementitious material derived from coir industry. International Journal of Emerging Trends in Engineering Research 8(8): 4496 - 4501. 